\title{
Manajemen Peningkatan Mutu Terpadu Pendidikan Agama Islam di Akademi Manajemen Administrasi Yogyakarta \\ Hidayatullah \\ Akademi Manajemen Administrasi Yogyakarta \\ danasani2011@gmail.com
}

\begin{abstract}
This study aims to empirically reveal Total Quality Management (TQM) of education, especially Islamic education. The problems that you want to know in this research are: 1. How is the implementation of integrated total quality management (TQM) for Islamic education at the Yogyakarta Administrative Management Academy? 2. What are the supporting factors for the implementation of TQM for Islamic religious education at the Yogyakarta Administrative Management Academy? 3. What are the obstacles faced in the implementation of TQM Islamic Religious Education at the Yogyakarta Administrative Management Academy? This type of research is qualitative. Using a sociological learning approach. Information gathering is obtained directly from informants through interviews, observations, and documentation. The information analysis method used is information reduction, information display, information verification, and conclusion confirmation. Overall, the implementation of TQM management of Islamic religious education at the Yogyakarta Administrative Management Academy shows significant results both in terms of cognitive and affective. Even so, customer service must be prioritized and improved.
\end{abstract}

Keywords: Quality Management, Islamic Education

\section{Pendahuluan}

Pendidikan agama adalah pendidikan pokok mendasar manusia yang harus diberikan kepada peserta didik pada setiap jenjang pendidikan formal mulai dari tingkat sekolah dasar (SD) sampai dengan perguruan tinggi (PT). Hal ini senada dengan dengan penjelasan undang-undang SISDIKNAS No. 20 Tahun 2003 pasal 3:

Pendidikan nasional berfungsi mengembangkan kemampuan dan membentuk watak serta peradaban bangsa yang bermartabat dalam rangka mencerdaskan kehidupan bangsa, bertujuan untuk berkembangnya potensi peserta didik agar menjadi manusia yang beriman dan bertaqwa kepada Tuhan Yang Maha Esa, berakhlak mulia, sehat, berilmu, cakap, kreatif, mandiri dan menjadi warga negara yang demokratis serta bertanggung jawab. ${ }^{1}$

Untuk merealisasikan hal tersebut bukanlah persoalan yang ringan, di samping mempersiapkan peserta didik untuk meningkatkan ilmu pengetahuan dan teknologi (IPTEK) diharapkan juga mampu meningkatkan

1UU SISDIKNAS No. 20 Tahun 2003. 
keimanan dan ketaqwaan (IMTAQ) terhadap Tuhan Yang Maha Esa. Peningkatan keimanan dan ketaqwaan dilakukan untuk mengantisipasi dampak negatif dari perkembangan ilmu pengetahuan dan teknologi. ${ }^{2}$ Salah satu usaha untuk mengantisipasi dampak negatif tersebut adalah dengan memberikan materi akhlak yang seimbang kepada peserta didik. Oleh karena itu ketentuan yang tercantum yang tercantum dalam undang-undang SISDIKNAS No. 20 tahun 2003 pasal 30 tentang pendidikan keagamaan wajib untuk dilaksanakan oleh semua komponen pendidikan baik pendidikan formal, non formal dan informal. ${ }^{3}$

Pendidikan pada umumnya dan pendidikan islam khususnya, tidaklah sekedar proses alih budaya atau alih ilmu pengetahuan (transfer of knowledge), tetapi juga sekaligus sebagai proses penanaman dan penumbuhan(transfer of value). Secara konseptual dapat dikatakan bahwa tujuan pendidikan islam adalah menjadikan manusia bertaqwa, yaitu manusia dapat mencapai kesuksesan hidup di dunia dan akhirat. ${ }^{4}$

Untuk merealisasikan harapan dan tujuan pendidikan islam tersebut bukanlah hal yang mudah. Hal ini dapat dilihat pada fenomena yang ada, seperti sebuah video perundungan yang dialami seorang remaja putri berinisial U (16), warga Kecamatan Gantar, Indramayu, Jawa Barat, yang dilakukan oleh dua temannya yakni N (16), dan D (15). Peristiwa itu terjadi di sebuah pemakaman umum di Dusun Pilangpayung Desa Lempuyang. ${ }^{5}$ Belum lagi tawuran antar pelajar seperti yang terjadi di Polrestro Depok dan Polsek Sukmajaya mengamankan enam pelajar yang diduga hendak tawuran di Jalan Ciliwung, Kecamatan Sukmajaya. Dari enam pelajar itu ditemukan satu perempuan kedapatan membawa celurit. ${ }^{6}$ Kasus pembuangan bayi di daerah Babarsari Sleman Yogyakarta yang dilakukan oleh seorang mahasiswi sebuah perguruan tinggi di Yogyakarta, ${ }^{7}$ menambah daftar panjang kenakalan yang terjadi di kalangan pelajar dan mahasiswa.

Dari beberapa catatan kasus kriminalitas di atas menunjukkan masih adanya kontradiksi antara idealitas dan realitas yang ada di masyarakat. Permasalahan besar yang dialami bangsa ini yang ditandai dengan krisis etika dalam kehidupan berbangsa dan bernegara dan konflik berkepanjangan

2Abdur Rahman, Pendidikan Agama Dan Keagamaan Visi, Misi Dan Aksi (Jakarta: Gemawindu Panca Perkasa, 2000), hal. 31

${ }^{3}$ Lihat UU SISDIKNAS No. 20 Tahun 2003, pasal 30 ayat 1-5 penjelasan tentang bentuk pendidikan agama, fungsi serta ketentuan tentang pendidikan keagamaan.

${ }^{4}$ Muslih Usa, Pendidikan Islam di Indonesia Antara Cita dan Fakta (Yogyakarta: PT. Tiara Wacana, 1991), hal. 43

${ }^{5}$ Harian Kompas online, berjudul, "usai-viral-video-remaja-putri-dianiayateman diunduh tanggal 15 Januari 2021 dari laman http://gg.gg/o9tr7

${ }^{6}$ Liputan 6 online berjudul "Polisi Amankan 6 Pelajar Diduga Hendak Tawuran", diunduh pada tanggal 15 Januari 2021 pada laman http://gg.gg/o9tsg

7Tribun News online berjudul " Mahasiswi Buang Bayi di Babarsari diunduh pada tanggal 15 Januari 2021 pada laman http://gg.gg/o9tut 
antar umat beragama, rendahnya komitmen dan kesadaran masyarakat, tawuran dan tindakan kriminalitas yang dilakukan para pelajar serta maraknya pergulan bebas di kalangan pelajar dan mahasiswa merupakan pekerjaan rumah yang cukup menyita perhatian semua kalangan khususnya di dunia pendidikan. Hal ini juga yang menjadi perhatian pihak Akademi Manajemen Administrasi Yogyakarta (AMA Yogyakarta) untuk mengambil sikap tegas dalam menangani kenakalan di kalangan mahasiswa. Salah satunya dengan mengelola secara professional, teratur dan terencana perkuliahan Pendidikan Agama Islam. Dengan kata lain pendidikan agama islam harus berorientasikan pada kualitas dan kepuasan pada pelanggan/ peserta didik.

Untuk mewujudkan idealitas tersebut maka sudah saatnya suatu lembaga pendidikan meningkatkan kualitas pendidikannya melalui manajemen peningkatan mutu sekolah termasuk di dalamnya Pendidikan Agama Islam. Manajemen peningkatan mutu sekolah adalah suatu metode peningkatan mutu yang menekankan bahwa peningkatan mutu harus bertumpu pada sekolah itu sendiri, mengaplikasikan sekumpulan teknik, mendasarkan pada kesediaan data kuantitatif, serta pemberdayaan semua komponen sekolah untuk secara terus menerus berkesinambungan meningkatkan kapasitas dan kemampuan organisasi sekolah guna memenuhi tuntutan dan kebutuhan peserta didik dan masyarakat. ${ }^{8}$

Manajemen peningkatan mutu sekolah adalah suatu metode peningkatan mutu yang menekankan bahwa peningkatan mutu harus bertumpu pada sekolah itu sendiri, mengaplikasikan sekumpulan teknik, mendasarkan pada kesediaan data kuantitatif, serta pemberdayaan semua komponen sekolah untuk secara terus menerus berkesinambungan meningkatkan kapasitas dan kemampuan organisasi sekolah guna memenuhi tuntutan dan kebutuhan peserta didik dan masyarakat. ${ }^{9}$ Termasuk di dalamnya dengan menerapkan konsep manajemen mutu atau TQM Total Quality Management dalam pembelajaran Pendidikan Agama Islam.

Dengan memperhatikan manajemen peningkatan mutu tersebut, Akademi Manajemen Administrasi Yogyakarta(AMA YO) berupaya meningkatkan kualitas mahasiswanya bukan saja ahli dalam manajemen admintrasi saja tetapi juga membekali mahasiswanya dengan pengetahuan agama yang memadai. AMA Yogyakarta sendiri berada di Jl. Pramuka No.7085 B Yogyakarta. Perguruan tinggi ini mempunyai mahasiswa kurang lebih 1000 mahasiswa. 90 persennya beragama Islam dan 10 persen adalah non muslim. Adapun program studi yang dibuka adalah ilmu manajemen dengan Konsentrasi Manajemen Administrasi Rumah Sakit, Manajemen hal. 1

8Departemen Pendidikan Nasional, Panduan Manajemen Sekolah (Jakarta : 1998),

9Ibid., hal. 1 
Administrasi Obat dan Farmasi dan Manajemen Administrasi Transportasi Udara.

Visi dan misi lembaga ini adalah "Menjadi sebuah perguruan tinggi yang unggul di tingkat nasional, professional, agamis dengan didukung kemampuan wiraswasta mandiri. Mendidik dan membentuk tenaga profesional di bidang manajemen administrasi yang cakap terampil, berbudi pekerti luhur, bertakwa dan berakhlak mulia, berjiwa kebangsaan, kreatif, inovatif, adaptif dan mempunyai komitmen tinggi bagi kemajuan bangsa. Serta Mewujudkan pendidikan tinggi yang unggul, berkualitas dan terjangkau oleh masyarakat. ${ }^{10}$

Dari visi misi tersebut diharapkan mahasiswa AMA Yogyakarta mempunyai wawasan tentang Manajemen yang luas tanpa meninggalkan nilai-nilai agama islam yang sudah diajarkan di kampus. Salah satu bentuk kongkret dari visi misi lembaga ini adalah peraturan yang mewajibkan mahasiswi muslim untuk memakai jilbab di dalam lingkungan kampus. Selain itu juga melarang mahasiswa putra memakai asesoris yang berlebihan seperti memakai anting, bertato dan larangan merokok di lingkungan kampus. ${ }^{11}$

Untuk mendukung ke arah tujuan tersebut, sudah semestinya proses belajar mengajar (PMB) yang harus berorientasikan pada pemenuhan tujuan institusional. AMA Yogyakarta selain mengembangkan ilmu Manajemen Adminstrasi yang sudah dikembangkan oleh banyak kampus serupa namun juga mengembangkan ilmu manajemen yang dijiwai dengan nilai-nilai islam.

\section{Metode Penelitian}

Prosedur yang digunakan dalam riset ini merupakan metodologi kualitatif. Nana Syaodih Sukmadinata, menerangkan riset kualitatif( qualitative research) yaitu suatu studi yang diperuntukan buat mendiskripsikan serta menganalisis fenomena, kejadian, kegiatan sosial, perilaku, keyakinan, anggapan, pemikiran orang secara orang ataupun kelompok. ${ }^{12}$ Tipe riset kualitatif digunakan dalam riset ini untuk menggambarkan, menganalisa serta menginterpretasikan keadaan-keadaan bersumber pada informasi yang penulis bisa galih secara lebih mendalam tentang penerapan manajemen TQM pendidikan agama Islam di AMA Yogyakarta.

Sumber data penelitian ini adalah semua yang terlibat terkait dengan obyek penelitian ini. Penulis menggunakan metode Sample Purposif

10 Visi Misi AMA Yogyakarta, diunduh pada tanggal 20 Desember 2020 pada laman http:/ /amayogyakarta.ac.id

11TIM BPAS, Buku panduan mahasiswa AMA Yogyakarta tahun 2020/2021, (Yogyakarta: AMA Yogyakarta), hal. 5

${ }^{12 N a n a}$ Syaodih Sukmadinata, Metode Penelitian Pendidikan, cet. 3 (Bandung: Rosda Karya, 2007), hal. 60 
sehingga dapat mengambil dari sumber-sumber yang kaya informasi. ${ }^{13}$ Untuk mendapatkan informasi yang lebih jelas tentang persoalan tersebut maka penulis melibatkan semua pengurus AMA Yogyakarta dan pihak yang terkait termasuk para dosen, mahasiswa dan staf administrasinya untuk dijadikan obyek penelitian. Semua akan dijadikan responden dalam penelitian ini.

Dalam pengumpulan data penulis menggunakan teknik observasi, wawancara, dan dokumentasi. Observasi digunakan untuk mendapatkan data pelaksanaan pembelajaran pendidikan agama Islam oleh para dosen di AMA Yogyakarta. Wawancara digunakan untuk mendapatkan data tentang pemahaman dosen terhadap metode peningkatan mutu dalam pengajaran pendidikan agama Islam.

\section{Pembahasan}

\section{A. Total Quality Management TQM dalam pendidikan agama Islam}

Penelitian yang bertema tentang penerapan TQM dalam pendidikan Islam sebelumnya berjudul Implementasi Manajemen Mutu Terpada (MMT) Pada Lembaga Pendidikan Islam di MI Ash-Siddiqiyyah-3 menyimpulkan bahwa implementasi manajemen mutu terpada di MI AshSiddiqiyyah-3 sudah tergolong baik, meski masih banyak persoalan yang belum terpecahkan dengan sempurna. ${ }^{14}$ Sedang hasil penelitian yang dilakukan Rubini menyebutkan bahwa mutu terpadu dalam dunia pendidikan membuat setiap orang berjanji untuk melayani orang lain berdasarkan setiap tuntutan pendidikan. ${ }^{15}$ Berbeda dengan Rina Priarni, ia menyimpulkan bahwa dalam mencapai keberhasilan suatu lembaga pendidikan, haruslan di terapkan satu paradigma TQM (total quality management) yang di dalamnya terdapat 10 karakteristik yang harus diterapkan dalam perusahan tersebut. ${ }^{16}$

Sementara itu Abdul Basyit menjelaskan bahwa peningkatan mutu pendidikan Islam bisa dilaksanakan jika seluruh aspek sumber daya yang ada dapat digunakan dan diberdayakan secara menyuruh. ${ }^{17}$ Hal lain dinyatakan oleh Furqon dalam penelitiannya, bahwa manajemen pendidikan agama islam di IPB meliputi program pengadaan dosen,

13. Ibid., hal. 101

14 . Syaefudin, Implementasi Manajemen Mutu Terpadu (MMT) Pada Lembaga Pendidikan Islam Jurnal Pendidikan Agama Islam, Vol. XV, No. 2, Desember 2018, hal. 244

15 . Rubini, Manajemen Mutu Pendidikan Islam, Jurnal Komunikasi dan Pendidikan Islam, Volume 6 No.2 tahun 2017, hal. 53

16. Rina Priarni, Aplikasi Total Quality Management Dalam Lembaga Pendidikan Islam, Jurnal Inspirasi, UNDARIS Semarang, Volume 1, No.1 Tahun 2017, hal. 200

17 . Abdul Basyit, Implementasi Manajemen Mutu Pendidikan Islam, Kordinat volume XVII, No. 1 April 2018 hal., 207 
manajemen penjadwalan kuliah PAI, manajemen pembelajaran serta adanya program tindak lanjut. ${ }^{18}$

Imam Mashud dalam "Quality Management Of Islamic Educational Institutions Service" menyatakan bahwa penerapan TQM di Madrasah Ibtidaiyah Al-Husna Ciledug Tangerang belum sepenuhnya memenuhi harapan pelanggan. Hal ini dibuktikan dari hasil penelitian ini yakni nilai pada masing-masing dimensi kualitas pelayanan masih dibawah angka 100. Artinya pelayanan kepada pelanggan perlu untuk ditingkatkan lagi. ${ }^{19}$

Dari beberapa hasil penelitian di atas dapat penulis simpulkan bahwa penerapan manajemen mutu atau TQM dalam dunia pendidikan sudah banyak diterapkan oleh lembaga pendidikan Islam. Namun dalam penerapannya masih ditemukan kekurangan, khususnya dalam memenuhi harapan dan kepuasan pelanggan. Padahal dalam TQM ditegaskan bahwa evaluasi dan perbaikan secara kontinyu adalah hal terpenting dalam menghasilkan produk atau jasa yang berkualitas.

David Decenzo mengatakan manajemen adalah proses efesiensi menuju kesuksesan obyektif dalam sebuah organisasi yang dikerjakan bersama-sama dengan orang lain, "Management is process of efficently achieving the objective of the organization with and through people". ${ }^{20}$ Sedang menurut Marry Parker Follet seperti yang dikutip oleh Ernie Trisnawati Sule, dalam buku Pengantar Manajemen, menyatakan bahwa manajemen adalah seni dalam menyelesaikan sesuatu melalui orang lain. Management is the art of getting things done through people. ${ }^{21}$

Sementara Fremont E Kast menyatakan, bahwa manajemen adalah pekerjaan mental (pikiran, intuisi, perasaan) yang dilaksanakan oleh orang-orang dalam konteks organisasi. Dari definisi ini dapat dijabarkan bahwa persoalan manajemen mencakup hal-hal sebagai berikut :

1. Mengkoordinir sumber daya manusia, material, dan keuangan ke arah tercapainya sasaran organisasi secara efektif dan efesien.

2. Menghubungkan organisasi dengan lingkungan luar dan menggapai kebutuhan masyarakat.

3. Mengembangkan iklim organisasi di mana orang dapat mengejar sasaran perseorangan (individu) dan sasaran bersama (collective)

${ }^{18}$ Furqon Syarif Hidayatullah, Manajemen Pendidikan Agama Islam Di Perguruan Tinggi Umum, Jurnal Pendidikan Islam, UIN Sunan Gunung Djati, volume XXVIII Bandung,2013, hal. 200

${ }^{19}$ Imam Mashud dkk, Quality Management Of Islamic Educational Institutions Service (Study Of Customer Satisfaction Analysis In Madrasah Ibtidaiyah Al-Husna Ciledug Tangerang City), International Journal of Educational Management and Innovation, Vol.2, No.1, January 2021, hal. 66

${ }^{20}$ David A Decenzo \& Stephen P Robbins, Human Resource Management, sixh edition ( New York: Jhon Wiley \& Inc. 1999), hal. 5

21Ernie Trisnawati Sule\& Kurniawan Saefullah, Pengantar Manajemen, edisi pertama, cet.II(Jakarta: Kencana, 2006), hal. 5 
4. Melaksanakan fungsi-fungsi tertentu yang dapat ditetapkan seperti menentukan sasaran, merencanakan, merakit sumber daya, mengorganisir, melaksanakan dan mengawasi.

5. Melaksanakan berbagai peranan antar pribadi, informasional, dan memutuskan (decisional).22

\section{B. Karakteristik Mutu dalam Pendidikan}

Memahami tentang mutu menjadi sangat penting sebagai pintu awal masuk memahami MMT (Manajemen Mutu Terpadu). Mutu adalah substansi pokok dari adanya MMT. Tujuan dari mutu adalah kepuasan pelanggan. Mutu memiliki pengertian yang bervariasi dari yang konvensional sampai yang lebih strategik. Definisi konvensional menyatakan bahwa mutu adalah gambaran karakteristik langsung dari suatu produk seperti: performansi (performance), estetika (estetics), dan sebagainya. Sedangkan definisi strategik menyatakan bahwa mutu adalah segala sesuatu yang mampu memenuhi keinginan atau kebutuhan pelanggan (meeting the needs of costomers). ${ }^{23}$

Sementara itu Soewarso Hardjosoedarmo dalam buku Total Quality Management, mengatakan bahwa TQM adalah penerapan metode kuantitatif dan pengetahuan kemanusiaan untuk:

1. Memperbaiki material dan jasa yang menjadi masukan organisasi,

2. Memperbaiki semua proses penting dalam organisasi,

3. Memperbaiki upaya memenuhi kebutuhan para pemakai produk dan jasa masa kini dan di waktu yang akan datang. ${ }^{24}$

Dalam bidang pendidikan mutu meliputi input, proses, output dan outcome. Input pendidikan dinyatakan bermutu jika siap berproses. Proses pendidikan bermutu apabila mampu menciptakan suasana yang PAKEMB (pembelajaran yang aktif, kreatif, menyenangkan, dan bermakna). Output dinyatakan bermutu jika hasil belajar akademik dan non akademik siswa tinggi. Outcame dinyatakan bermutu apabila lulusan cepat terserap di dunia kerja, gaji wajar, semua pihak mengakui kehebatan lulusan dan merasa puas.

Manfaat mutu bagi dunia pendidikan diantaranya :

1. Meningkatkan pertanggungjawaban (akuntabilitas) sekolah kepada masyarakat dan atau pemerintah yang telah memberikan semua biaya kepada sekolah.

2. Menjamin mutu lulusannya

3. Bekerja lebih profesiaonal

${ }^{22}$ Fremont E Kast \& James E Resenzweing, Organisasi dan Manajemen, edisi keempat, terj. Drs. A Hasyimi Ali (Jakarta: Bumi Aksara, 1998), hal. 7

23Vincent Gaspersz, Total Quality Management, cet III ( Jakarta: Gramedia Pustaka Utama, 2003) hal. 4

24Soewarso Hardjosoedarmo, Total Quality Management, cet.III ( Yogyakarta: Andi Offset 2002), hal. 2 
4. Meningkatkan persaingan yang sehat. ${ }^{25}$

Mutu dalam dunia pendidikan memiliki 13 karakteristik seperti berikut :

1. Kinerja (performa) berkaitan dengan aspek lingkungan fungsional sekolah. Misalnya kinerja guru dalam mengajar baik, memberikan penjelasan, meyakinkan, sehat dan rajin mengajar, dan menyiapkan bahan pelajaran lengkap. Pelayanan administratif dan educatif sekolah baik yang ditandai hasil belajar tinggi, lulusannya banyak, putus sekolah sedikit, dan yang lulus tepat waktu banyak. Akibat kinerja yang baik maka sekolah tersebut menjadi sekolah favorit.

2. Waktu wajar (timeline)selesai dengan waktu yang wajar. Misalnya memulai dan mengakhiri pelajaran tepat waktu. Waktu ulangan tepat. Batas waktu pemeberian pekerjaan sekolah wajar. Waktu guru untuk naik pangkat wajar.

3. Handal (reability) usia pelayanan prima bertahan lama. Misalnya pelayanan prima yang diberikan sekolah bertahan dari tahun ke tahun, mutu sekolah tetap bertahan. Sebagai sekolah favorit bertahan dari tahun ke tahun. Sekolah menjadi juara tertentu bertahan dari tahun ke tahun. Guru jarang sakit. Kerja keras guru bertahan dari tahun ke tahun.

4. Daya tahan (durability) tahan banting. Misalnya meskipun krisis moneter, sekolah masih tetap bertahan, tidak tutup. Siswa dan guru tidak putus asa dan selalu sehat.

5. Indah (estetis). Misalnya eksterior dan interior sekolah ditata menarik. Taman ditanami bunga dan terpelihara dengan baik. Guru-guru membuat media pendidikan yang menarik. Warga sekolah berpenampilan rapi.

6. Hubungan manusiawi (personal interface) menjunjung tinggi nilai-nilai moral dan profesionalisme. Misalnya warga sekolah saling menghormati, baik warga intern mampu ekstern sekolah, demokratis dan menghargai profesionalisme.

7. Mudah penggunaannya (easy of use) sarana dan prasarana dipakai. Misalnya aturan-aturan sekolah mudah diterapkan. Buku-buku perpustakaan muda dipinjam dan dikembalikan tepat waktu. Penjelasan guru di kelas mudah dimengerti siswa, contoh soal mudah dipahami. Demontrasi praktek mudah diterapkan siswa.

8. Bentuk khusus (feuture): keunggulan tertentu. Misalnya sekolah ada yang unggul dengan hampir semua lulusannya diterima di universitas bermutu. Unggul dengan bahasa Inggrisnya. Unggul dengan penguasaan teknologi informasinya (komputerisasi). Ada yang unggul dengan karya ilmiah kesenian atau olah raga.

${ }^{25}$ Husaini Usman, Manajemen, Teori, Praktek... hal. 479-480 
9. Standar tertentu (confermance to specification) memenuhi standar tertentu. Misalnya: sekolah sudah memenuhi standar pelayanan minimal (SPM), sekolah sudah memenuhi standar minimal ujian nasional atau sekolah sudah memenuhi ISO 9001:2000 atau sekolah sudah memenuhi TOEFL dengan skor 650

10. Konsistensi (consistency) keajegan, konstan, atau stabil. Misalnya mutu sekolah dari dahulu sampai sekarang tidak menurun seperti harus mengatrol nilai siswa-siswanya. Warga sekolah konsisten antar perkataan dan perbuatan. Apabila berkata tidak berbohong, apabila berjanji ditepati, dan apabila dipercaya tidak mengkhianati

11. Seragam (uniformity) tanpa variasi, tidak tercampur. Misalnya sekolah menyeragamkan pakaian sekolah dan pakaian dinas. Sekolah melaksanakan atauran, tidak pandang bulu atau pilih kasih.

12. Mampu melayani (servicebility) mampu memberikan pelayanan prima. Misalnya sekolah menyediakan kotak saran dan saran-saran yang masuk mampu dipenuhi dengan sebaik-baiknya. Sekolah mampu memberikan pelayanan primanya kepada pelanggan sekolah sehingga semua pelanggan merasa puas.

13. Ketepatan (accuracy) ketepatan dalam pelayanan. Misalnya sekolah mampu memberikan pelayanan sesuai dengan yang diinginkan pelanggan sekolah, guru-guru tidak salah dalam menilai sisiwasiswanya. Semua warga sekolah bekerja dengan teliti. Jam belajar di sekolah berlangsung tepat waktu. ${ }^{26}$

\section{Manajemen Mutu Terpadu}

Pada dasarnya manajemen mutu (Quality Management) atau manajemen mutu terpadu (Total Quality Management) didefinisikan sebagai suatu cara meningkatkan performansi secara terus menerus (Continous Performance Improvement) pada setiap level operasi atau proses, dalam setiap area fungsional dari mutu organisasi dengan menggunakan semua sumber daya manusia dan modal yang tersedia.

ISO 8402 (Quality Vacabulary) mendefinisikan manajemen mutu sebagai semua aktifitas manajemen secara keseluruhan dan menentukan kebijaksanaan kualitas, tujuan-tujuan dan tanggung jawab, serta mengimplementasikannya melalui alat-alat seperti perencanaan kualitas (Quality Planning), jaminan kualitas Assurance) dan peningkatan kualitas ( Quality Improvement). Tanggung jawab untuk manajemen mutu ada pada semua level dari manajemen, tetapi harus dikendalikan oleh manajemen puncak (Top Management), dan implementasinya harus melibatkan semua anggota organisasi.

Departemen pertahanan Amarika (The U.S. Department of Defense) mendefinisikan manajemen mutu terpadu sebagai filosofi dan

26. Ibid, hal. 481-482 
sekumpulan petunjuk prinsip-prinsip yang menjadi landasan untuk perbaikan terus-menerus dari suatu organisasi. Manajemen mutu terpadu adalah penerapan metode-metode kuantitatif dan sumber daya manusia untuk meningkatkan kualitas material dan pelayanan yang dipasok dari suatu organisasi, semua proses dalam organisasi, dan memenuhi derajat kebutuhan pelanggan baik pada saat sekarang maupun di masa yang akan datang. ${ }^{27}$

Dari berbagai definisi di atas dapat ditarik suatu kesimpulan bahwa manajemen mutu terpadu (TQM) harus fokus pada perbaikan terus menerus untuk memenuhi kepuasan pelanggan. Dengan demikian manajemen mutu terpadu berorientasi pada proses yang mengintegrasikan semua sumber daya manusia, pemasok-pemasok (supplier) dan para pelanggan (customer) di lingkungan perusahaan (corporate environment).

\section{Hasil Penelitian}

A. Implementasi Manajemen Pendidikan Agama Islam Terpadu di Akademi Manajemen Administrasi Yogyakarta

Akademi Administrasi Yogyakarta adalah kampus perguruan tinggi di bawah yayasan Rajawali Lang-lang Global Yogyakarta. Salah satu visi dan misinya adalah membentuk pribadi mahasiswa yang cerdas intektual dan cerdas spiritual, pribadi yang memiliki kompetensi ilmuilmu umum namun tetap memiliki integritas yang tinggi dan komitmen dalam berpegang teguh kepada nilai-nilai agama dan moral. Untuk mewujudkan idealitas tersebut, maka dibentuklah lembaga yang bernama Bagian Pengembangan Akhlak Spiritual (BPAS). Lembaga ini dibentuk untuk memberikan pelayanan terbaik untuk mahasiswa AMA Yogyakarta khususnya di bidang akhlak spiritual. Hal ini sebagaimana diungkapkan oleh direktur AMA Yogyakarta bapak H. Moch. Rofik, S.T., MM saat wawancara dengan penulis. ${ }^{28}$

Selain itu Bapak Moch. Rafik, menambahkan bahwa lembaga BPAS dibentuk dalam rangka pencapaian service excellent bagi mahasiswa khususnya dan citivitas akademika pada umumnya. Tidak lupa kami menghimbau kepada segenap civitas akademika untuk ikut berperan aktif dalam mendukung dan mengawal program pembinaan akhlak mahasiswa, karena keberhasilan mahasiswa merupakan keberhasilan kita dan sebaliknya kegagalan mereka berarti kegagalan kita. Mereka adalah anak sekaligus keluarga bagi kita, sehingga tanggungjawab pendidikan mereka adalah tanggungjawab kita bersama. ${ }^{29}$

27. Vincent Gaspersz, Total Quality Management... hal. 6

28. Wawancara dengan direktur AMA Yogyakarta H. Moch. Rofik, S.T., MM, tanggal 5 Januari 2021

${ }^{29}$ Wawancara dengan direktur AMA Yogyakarta 
Dari hasil wawancara tersebut dapat penulis simpulkan bahwa implementasi manajemen mutu dalam pembelajaran Pendidikan Agama Islam di AMA Yogyakarta sudah tepat. Karena hal ini sesuai dengan prinsip manajemen mutu khususnya dalam pendidikan yakni mampu melayani (servicebility) : mampu memberikan pelayanan secara prima.

\section{B. BPAS dan Ruang Lingkup Kerjanya}

BPAS AMA Yogyakarta adalah sebuah bagian atau unit kerja di bawah naungan dan koordinasi Wakil Direktur 1 bidang akademik dan pengajaran dan secara khusus mendapatkan amanah untuk mengawal tercapainya visi lembaga : "Menjadi perguruan tinggi yang berwawasan global, kebangsaan dan agamis". Secara lebih spesifik bagian ini bergerak dalam bidang pengembangan akhlak spiritual dan fokus dari objek formalnya adalah semua mahasiswa AMA Yogyakarta dengan berbagai latarbelakang agamanya masing-masing, dalam arti cakupan wilayah kerjanya pada mahasiswa beragama yang diakui secara sah oleh Negara Republik Indonesia. Untuk dapat memberikan bekal ilmu pengetahuan dan wawasan yang luas dan membentuk pribadi mahasiswa yang berakhlak mulia, serta menciptakan susasana agamis di lingkungan kampus, maka BPAS AMA Yogyakarta merancang seperangkat program khas yang sengaja disiapkan dan dengan harapan setelah mahasiswa selesai studi di kampus ini mampu menjadi kader-kader teladan yang unggul di masyarakatnya, memiliki integritas tinggi dan komitmen dalam berpegang teguh dengan nilai-nilai kebaikan, baik berkaitan dengan hubungan vertikal individu dengan Rabbnya maupun hubungan horisontal dengan sesama manusia/ lingkungan. ${ }^{30}$

Adapun visi BPAS AMA Yogyakarta adalah "Menjadi unit kerja yang mengantarkan mahasiswa menjadi insan yang beriman, berakhlak mulia dan memiliki komitmen tinggi dalam memegang nilai-nilai kebenaran", sedangkan misi BPAS AMA Yogyakarta adalah 1) Mengamalkan dan mengembangkan ajaran agama dengan benar dalam kehidupan sehari-hari. 2) Membekali mahasiswa dengan pengetahuan dan wawasan keagamaan yang luas, serta memiliki akhlak mulia. 3) Menciptakan suasana agamis di lingkungan kampus. 4) Menjadikan mahasiswa di dalam teladan kebaikan di lingkungannya setelah menyelesaikan aktivitas kuliahnya.

\section{Prinsip Pengembangan Kurikulum}

Kurikulum Pendidikan Agama Islam di AMA Yogyakarta mengacu pada kurikulum yang komplit. Artinya kurikulum PAI dirancang saling terkait antara perkuliahan agama dengan program-program BPAS yang lainnya misalnya hafalan surat pendek, hafalan bacaan sholat dan

30TIM. BPAS. Buku Pedoman Kurikulum dan Pembinaan Akhlak Spiritual Mahasiswa AMA Yogyakarta, tahun 2018, hal. 5 
sebagainya. Hal ini sebagaimana disampaikan oleh wakil kepala BPAS AMA Yogyakarta Bapak Ustad Muhlisin, S.E.Sy. ${ }^{31}$ Adapun keterkaitan antara perkuliahan agama dan program BPAS yang dimaksud adalah sebagai berikut :

1. Integratif-interkonektif

Kurikulum yang integratif adalah sebuah konsep kurikulum BPAS yang didesain agar antara program yang satu dengan program yang lainnya saling terkait, mendukung dan saling melengkapi. Selain itu agar terdapat korelasi konstruktif antara perkuliahan PA, Kegiatan, dan Bimbingan Sertifikasi sesuai program dan ketentuan yang berlaku pada masing-masing agama.

2. Student Center Learning (SCL)

Pendidikan bukan sekedar mentransfer ilmu pengetahuan kepada mahasiswa, namun lebih ditekankan pada membimbing, mendidik dan mendampingi mahasiswa menjadi lebih baik. Oleh karena itu dibutuhkan sebuah sikap menghargai kepada mahasiswa dengan menjadikan mahasiswa bukan sebagai objek pembelajaran, tetapi sebagai subjek pembelajaran. Sehingga kegiatan belajar mengajar lebih ditekankan pada studi kritis, bukan hanya sekedar mendoktrin mahasiswa. ${ }^{32}$

\section{Kriteria Kelulusan}

Untuk nilai kelulusan mata kuliah Pendidikan Agama Islam, TIM BPAS AMA Yogyakarta punya standar tersendiri. Mahasiswa dinyatakan tuntas secara minimal telah menyelesaikan studi/ program BPAS AMA Yogyakarta, apabila telah menempuh Mata Kuliah Syiar dan Sertifikasi sesuai ketentuan yang berlaku. Sebagaimana dijelaskankan ustad Muhlisin, S.E.Sy saat wawancara dengan penulis. ${ }^{33}$

"Adapun kreteria kelulusan tersebut adalah Mahasiswa bisa dinyatakan lulus kuliah/ studi BPAS AMA Yogyakarta, apabila perolehan nilai mata kuliah pada masing-masing program tiap semester mencapai akumulasi minimal B atau setara nilai 70 dengan catatan kehadiran dalam mengikuti kegiatan minimal 75 \% dari total pertemuan semestinya." tambah Ustad Muhlisin, S.E, Sy

Dari paparan di atas dapat penulis simpulkan bahwa kreteria kelulusan perkuliahan pendidikan agama Islam termasuk dalam katagori tinggi, sebab setiap mahasiswa harus mencapai nilai minimal 70. Standar nilai 70 ini sebagai bentuk menjaga kualitas kemampuan mahasiswa khusunya dalam perkuliahan pendidikan agama Islam.

${ }^{31}$ Wawancara dengan wakil ketua BPAS Bapak Muhlisin, S.E.Sy., tanggal 2 Februari 2021

32TIM BPAS, Buku Pedoman Kurikulum,.. hal. 6

${ }^{33}$ Wawancara dengan wakil BPAS 
Dalam menentukan kualifikasi mahasiswa, BPAS telah menetapkan rentang penilaian yang hendaknya digunakan sebagai acuan oleh setiap dosen/ pembimbing kuliah dan kegiatan di lingkungan BPAS. Berikut ini kita sampaikan rentang penilaian untuk Mata Kuliah/ kegiatan BPAS :

Tabel 1. Rentang Nilai Mata Kuliah dan Kegiatan

\begin{tabular}{|c|c|c|}
\hline No & Rentang Nilai & Predikat \\
\hline 1. & Nilai $64-69$ & C \\
\hline 2. & Nilai $70-84$ & B \\
\hline 3. & Nilai $85-99$ & A \\
\hline
\end{tabular}

Adapun komposisi penilaian pada Mata Kuliah dan kegiatan BPAS AMA Yogyakarta, tidak hanya mengacu pada hasil kerja yang diukur secara kognitif semata, namun juga melibatkan aspek/ variabel psikomotorik dan afektif mahasiswa, sehingga untuk alasan validitas nilai, Nilai Akhir Mata Kuliah Pendidikan Agama I, II, Ibadah, Sosiologi Agama, Syiar dan Sertifikasi, BPAS tidak hanya mempertimbangkan dari nilai ujian teori dari Mata Kuliah wajib saja, namun akan memasukkan nilai-nilai ujian pada Mata Kuliah/ kegiatan pendamping, seperti mutabaah, jurnal, sharing dan lain-lain.

Tebel 2. Komposisi Penilaian Mata Kuliah dan Kegiatan

\begin{tabular}{|c|l|c|}
\hline No & \multicolumn{1}{|c|}{ Komposisi } & Prosentase \% \\
\hline 1. & $\begin{array}{l}\text { Nilai MID/ UAS Mata Kuliah } \\
\text { wajib/ reguler }\end{array}$ & $75 \%$ \\
\hline 2. & Mutabaah dan Jurnal & $10 \%$ \\
\hline 3. & Pertanyaan/ tugas & $5 \%$ \\
\hline 4. & Sharing/ Mentoring/ Iltiqa' & $10 \%$ \\
\hline
\end{tabular}

Dari paparan di atas dapat penulis tarik kesimpulan bahwa penerapan manajemen mutu pendidikan agama Islam di AMA Yogyakarta dalam penyusunan kurikulum dan penilaian hasil mengacu pada prinsip bentuk khusus (feuture) yakni keunggulan tertentu. Keunggulan yang dimaksud adalah menjadikan mahasiswa lebih baik dalam memahami dan mengamalkan agama islam dalam kehidupan sehari-hari. Hal ini sesuai dengan tujuan dari pendidikan nasional yakni berkembangnya potensi peserta didik agar menjadi manusia yang beriman dan bertaqwa kepada Tuhan Yang Maha Esa, berakhlak mulia, sehat, berilmu, cakap, kreatif, mandiri dan menjadi warga negara yang demokratis serta bertanggung jawab.

Kurikulum BPAS AMA Yogyakarta berbasis Kegiatan IntegratifInterconectif terdiri dari dua macam, yaitu mata kuliah prasyarat dan mata 
kuliah tidak bersyarat. Mata kuliah prasyarat, yaitu Mata Kuliah Pendidikan Agama 1, II dan Bimbingan Sertifikasi, sedangkan mata kuliah tidak bersyarat meliputi Sharing, Tahsin dan Tahfizh Surat Pendek/ Doa. Untuk terwujudnya program tersebut diatas, maka diselenggarakan program-program pendukung, antara lain Mutabaah (Islam), Jurnal Harian/ Mingguan. Untuk lebih jelasnya, kuliah BPAS AMA Yogyakarta dapat dijabarkan dalam tabel sebagai berikut:

Tabel 2. Skema Program Kuliah dan Bimbingan

\begin{tabular}{|c|c|c|c|}
\hline No & Sem & Program & Keterangan \\
\hline & & A. Pendidikan Agama I & Wajib \\
\hline 1. & I & $\begin{array}{l}\text { A. Mentoring (sharing) } \\
\text { B. Mutabaah dan Jurnal } \\
\text { 1. Mutaba'ah } \\
\text { 2. Jurnal } \\
\text { Harian/Mingguan }\end{array}$ & \begin{tabular}{l}
\multicolumn{2}{l}{ Dilaksanakan } \\
UKM, nilai plus \\
untuk \\
Kuliah \\
Pendidikan \\
Agama I
\end{tabular} \\
\hline \multirow{3}{*}{2.} & \multirow{3}{*}{ II } & A. Pendidikan Agama II & Wajib \\
\hline & & B. Tahsin & $\begin{array}{ll}\text { Wajib } & \text { bagi } \\
\text { mahasiswa } & \\
\text { muslim } & \\
\end{array}$ \\
\hline & & $\begin{array}{l}\text { C. Mutabaah dan Jurnal } \\
\text { 1. Mutaba'ah } \\
\text { 2. Jurnal } \\
\text { harian/Mingguan }\end{array}$ & $\begin{array}{l}\text { Nilai plus untuk } \\
\text { Mata Kuliah } \\
\text { Pendidikan } \\
\text { Agama II }\end{array}$ \\
\hline \multirow[b]{2}{*}{3.} & \multirow[b]{2}{*}{ III } & A.Mata Kuliah Ibadah & Wajib \\
\hline & & $\begin{array}{l}\text { B. Mutabaah dan Jurnal } \\
\text { 1. Mutaba'ah } \\
\text { 2. Jurnal } \\
\text { Harian/Mingguan }\end{array}$ & $\begin{array}{lr}\text { Nilai plus } & \text { untuk } \\
\text { Mata } & \text { Kuliah } \\
\text { Ibadah } & \end{array}$ \\
\hline \multirow[b]{2}{*}{4} & \multirow[b]{2}{*}{ IV } & $\begin{array}{l}\text { A. Mata Kuliah Sosiologi } \\
\text { Agama }\end{array}$ & Wajib \\
\hline & & $\begin{array}{l}\text { B. Mutabaah dan Jurnal } \\
\text { 1. Mutaba'ah } \\
\text { 2. Jurnal } \\
\text { Harian/Mingguan }\end{array}$ & $\begin{array}{l}\text { Nilai plus } \\
\text { Mata } \quad \text { Kuliah } \\
\text { Sosiologi Agama }\end{array}$ \\
\hline 5 & $\mathrm{~V}$ & $\begin{array}{l}\text { Mata Kuliah Syiar dan } \\
\text { Sertifikasi }\end{array}$ & $\begin{array}{l}\text { Teori dan } \\
\text { praktikum } \\
\text { (Bimbingan), } 14 \\
\text { kali pertemuan }\end{array}$ \\
\hline
\end{tabular}




\begin{tabular}{|c|c|c|c|}
\hline & & & $\begin{array}{l}\text { ditambah } 2 \text { kali } \\
\text { evaluasi/ ujian }\end{array}$ \\
\hline 6 & $\begin{array}{c}\text { All } \\
\text { Semester }\end{array}$ & Konseling Mahasiswa & $\begin{array}{l}\text { Mahasiswa } \\
\text { dengan semua } \\
\text { latar belakang } \\
\text { agama, sesuai } \\
\text { waktu } \\
\text { kesepakatan dan } \\
\text { keperluan. }\end{array}$ \\
\hline
\end{tabular}

Dari tabel di atas dapat diambil kesimpulan bahwa perkulihan pendidikan agama Islam di AMA Yogyakarta mempunyai ciri khas tersendiri berbeda dengan kampus lainnya. Keberadaan materi agama di setiap jenjang semester inilah yang menjadi daya tarik dan keunggulan perkuliahan pendidikan agama islam di AMA Yogyakarta. Program ini juga menjadikan karakteristik kampus AMA Yogyakarta terlihat lebih agamis.

E. Factor Pendukung Implementasi Manajemen Mutu Pendidikan Agama Islam Di Ama Yogyakarta

Setiap penerapan program manajemen mutu di suatu lembaga pendidikan selalu ada pendukungnya yang menjadi kesuksesan implementasi manajemen mutu tersebut. Adapun factor pendukung pelaksanaan manajemen mutu pendidikan agama islam di AMA Yogyakarta adalah : adanya media elektronik dan komputer serta menggunakan media internet sebagai sarana komunikasi dalam pembelajaran. Selain itu juga pelayanan yang ramah dari para pengurus BPAS dan selalu sigap dalam mengatasi masalah yang dikeluhkan para dosen Pendidikan Agama Islam. Seperti yang dijelaskan oleh Ustad Fahmi M.Pd.I saat diwawancarai penulis. ${ }^{34}$

Sementara itu Ustad Muhlisin SE, Sy menambahkan bahwa kekompakan TIM BPAS AMA Yogyakarta dalam menjalankan semua program - program BPAS adalah kunci utama kesuksesan dalam memberikan pelayanan terbaik khususnya dalam perkuliahan Pendidikan Agama Islam. ${ }^{35}$

Dari paparan dia atas dapat disimpulkan bahwa factor pendukung berhasilnya program manajemen peningkatan mutu terpadu pendidikan agama Islam di AMA Yogyakarta tidak lepas dari kekuatan dan kekompakan TIM BPAS dalam merencanakan dan memberikan pelayanan terbaik untuk semua pihak. Hal ini sesuai dengan prinsip manajemen mutu dalam pendidikan yakni kinerja (performa) yang baik: berkaitan dengan aspek lingkungan fungsional perguruan tinggi.

\footnotetext{
${ }^{34}$ Wawancara dengan ustad Fahmi, M.Pd.I dosen Pendidikan Agama Islam AMA Yogyakarta, tanggal 3 Februari 2021

35Wawancara dengan wakil BPAS
} 
Misalnya: Pelayanan administratif dan educatif pihak kampus sangat baik yang ditandai hasil belajar tinggi, lulusannya banyak, droup out sedikit, dan yang lulus tepat waktu banyak. Akibat kinerja yang baik maka perguruan tinggi tersebut menjadi perguruan tinggi favorit.

F. Kendala dalam penerapan Manajemen mutu terpadu Pendidikan Agama Islam AMA Yogyakarta

Penerapan Manajemen mutu pendidikan agama islam terpadu di AMA Yogyakarta ini tidak lepas dari hambatan atau kendala. Adapun kendala yang dihadapi dalam penerapan manajemen mutu pendidikan agama islam di AMA Yogyakarta sangatlah beragam. Baik dari mahasiswa, dosen bahkan dari pihak TIM BPAS sendiri.

“Keterlambatan pengisian kartu KRS oleh mahasiswa misalnya, ini bisa menjadikan proses penginputan data presensi untuk perkuliahan PAI jadi terlambat. Belum lagi mereka salah input data pengisisan KRS, yang seharusnya masuk kelas A tapi diinput masuk kelas B. Hal ini juga yang menambah PR bagi Tim BPAS, Jelas Ustad Muhlisin SE.Sy. saat diwawancara oleh penulis. ${ }^{36}$

Sementara itu dari para dosen yang menjadi kendala dalam perkuliahan pendidikan agama islam diantaranya jarak yang jauh dari jangkauan internet, baik itu dialami dosen maupun mahasiswa. Ditambah lagi kuota internet yang terbatas merupakan salah satu yang menghambat KBM secara khususnya dalam masa perkuliahan secara daring. Seperti yang diungkapkan oleh Ustad Fahmi M.Pd.I salah satu dosen Pendidikan Agama Islam AMA Yogyakarta saat wawancara dengan penulis. ${ }^{37}$

Berdasarkan paparan di atas dapat penulis simpulkan bahwa adanya kendala program manajemen peningkatan mutu pendidikan agama Islam di AMA Yogyakarta tidak lepas dari latar belakang mahasiswa. Perbedaan budaya dan kemampuan mahasiswa dalam mengoperasikan IT adalah proplematika pada setiap perguruan tinggi yang mahasiswanya berasal dari berbagai daerah di Indonesia. Sebab tidak semua mahasiswa terbiasa dengan budaya digital. Oleh karena itu wajar kalau sampai banyak terjadi keterlambatan baik saat proses perkuliahan maupun pada saat input data.

Sementara dari pihak mahasiswa mengeluhkan keterlambatan dari dosen pengampu kuliah pendidikan agama Islam sangat disayangkan oleh mahasiswa, karena akan mengurangi durasi waktu mengajar. Ditambah lagi dari pihak BPAS yang sering memberikan informasi mendadak misalnya tentang pengumpulan buku "Mutaba'ah". Hal ini diungkapkan oleh JD saat wawancara dengan penulis. ${ }^{38}$

36Ibid.

37Wawancara dengan ustad Fahmi, M.Pd.I

38 Wawancara dengan JD, mahasiswa AMA Yogyakarta tanggal 15 Januari 2021 


\section{Kesimpulan}

Penerapan Total Quality Management (TQM) pendidikan agama Islam di AMA Yogyakarta berdasarkan hasil penelitian ini menunjukkan belum sepenuhnya bisa dikatakan sempurna. Terbukti dengan adanya keluhan yang berkaitan tentang pelayanan kepada pelanggan. Padahal dalam konsep manajemen mutu dijelaskan bahwa kepuasan pelangan adalah hal utama. Meski demikian konsep yang ditawarkan oleh AMA Yogyakarta dengan lembaga Bagian Pengembangan Akhlaq Spiritual (BPAS) patut diapresiasi keberadaannya. Sebagai bentuk usaha untuk memenuhi kekurangan yang ada pada perkuliahan pendidikan agama Islam.

Adapun factor pendukung dalam penerapan manajemen mutu ini adalah adanya ghirah dalam memberikan pelayanan dan kekompakan tim BPAS. Selain itu dukungan dari stockholder AMA Yogyakarta adalah modal yang utama.

Sebagai saran, perlu kiranya AMA Yogyakarta lebih meningkatkan lagi mutu pelayanannya pada pelanggan khususnya dalam kedisiplinan, baik bagi TIM BPAS, Dosen dan Mahasiswanya. Dan bagi mahasiswa kemampuan mengoperasikan gawai atau gadget untuk saat ini adalah hal terpenting yang tidak bisa dianggap remeh seperti saat pandemi ini. Untuk itu diharapkan mahasiswa bisa belajar tentang IT di luar jam-jam perkuliahan untuk meningkatkan kemampuan ITnya.

\section{Daftar Pustaka}

Abdul Basyit. Implementasi Manajemen Mutu Pendidikan Islam. Kordinat. Volume XVII. No. 1 April 2018.

Abdur Rahman. Pendidikan Agama Dan Keagamaan Visi, Misi Dan Aksi (Jakarta: Gemawindu Panca Perkasa. 2000

David A Decenzo \& Stephen P Robbins. Human Resource Management. sixh edition. New York: Jhon Wiley \& Inc. 1999.

Departemen Pendidikan Nasional. Panduan Manajemen Sekolah Jakarta: 1998.

Ernie Trisnawati Sule\& Kurniawan Saefullah. Pengantar Manajemen. Edisi pertama. cet.II. Jakarta: Kencana. 2006.

Fremont E Kast \& James E Resenzweing. Organisasi dan Manajemen. Edisi keempat. terj. Hasyimi Ali. Jakarta: Bumi Aksara. 1998

Furqon Syarif Hidayatullah. Manajemen Pendidikan Agama Islam di Perguruan Tinggi Umum. Jurnal Pendidikan Islam. UIN Sunan Gunung Djati. volume XXVIII Bandung. 2013.

Harian Kompas online, berjudul. "Usai-viral-video-remaja-putri-dianiaya-teman diunduh tanggal 15 Januari 2021 dari laman http://gg.gg/o9tr7

http:/ / amayogyakarta.ac.id

Imam Mashud dkk.. Quality Management Of Islamic Educational Institutions Service (Study Of Customer Satisfaction Analysis In Madrasah Ibtidaiyah AlHusna Ciledug Tangerang City). International Journal of Educational Management and Innovation. Vol. 2. No.1. January 2021. 
Jhon M Echols \& Hassan Shadily. Kamus Inggris - Indonesia. Cet XXII. Jakarta: Gramedia. 1996.

Liputan 6 online berjudul "Polisi Amankan 6 Pelajar Diduga Hendak Tawuran". diunduh pada tanggal 15 Januari 2021 pada laman http://gg.gg/o9tsg

Muslih Usa. Pendidikan Islam di Indonesia Antara Cita dan Fakta. Yogyakarta: PT. Tiara Wacana. 1991.

Nana Syaodih Sukmadinata. Metode Penelitian Pendidikan. Cet. 3. Bandung:Rosda Karya. 2007.

Pius A Partanto \& M dahlan Al Barry. Kamus Ilmiah Populer. Surabaya: Arkola.

Rina Priarni. Aplikasi Total Quality Management Dalam Lembaga Pendidikan Islam. Jurnal Inspirasi. UNDARIS Semarang. Volume 1. No. 1 Tahun 2017.

Rubini. Manajemen Mutu Pendidikan Islam. Jurnal Komunikasi dan Pendidikan Islam. Volume 6 No. 2 tahun 2017.

Sugiono. Metode Penelitian Kuantitatif Kualitatif dan REDD. Bandung: Alfabeta. 2017.

Syaefudin. Implementasi Manajemen Mutu Terpadu (MMT) Pada Lembaga Pendidikan Islam Jurnal Pendidikan Agama Islam. Vol. XV. No. 2. Desember 2018.

TIM BPAS. Buku panduan mahasiswa AMA Yogyakarta tahun 2020/2021. AMA Yogyakarta.

Tribun News online berjudul " Mahasiswi Buang Bayi di Babarsari diunduh pada tanggal 15 Januari 2021 pada laman http://gg.gg/o9tut

UU SISDIKNAS No. 20 Tahun 2003. 